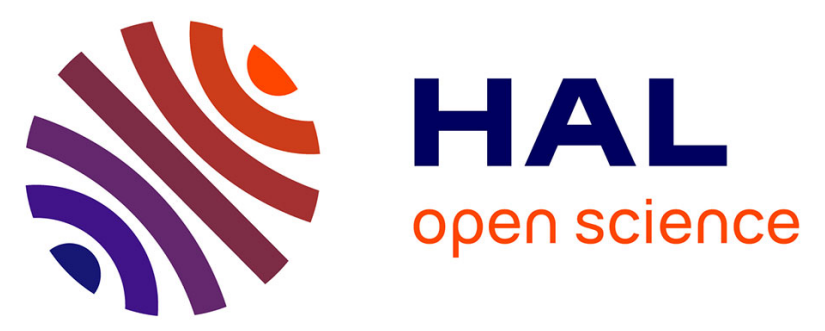

\title{
CO Hydrogenation on Cobalt-Based Catalysts: Tin Poisoning Unravels CO in Hollow Sites as a Main Surface Intermediate
}

Anaëlle Paredes-Nunez, Davide Lorito, Laurence Burel, Debora Motta-Meira, Giovanni Agostini, Nolven Guilhaume, Yves Schuurman, Frédéric Meunier

\section{To cite this version:}

Anaëlle Paredes-Nunez, Davide Lorito, Laurence Burel, Debora Motta-Meira, Giovanni Agostini, et al.. CO Hydrogenation on Cobalt-Based Catalysts: Tin Poisoning Unravels CO in Hollow Sites as a Main Surface Intermediate. Angewandte Chemie International Edition, 2018, 57 (2), pp.547-550. 10.1002/anie.201710301 . hal-01688174

\section{HAL Id: hal-01688174 https://hal.science/hal-01688174}

Submitted on 8 Oct 2021

HAL is a multi-disciplinary open access archive for the deposit and dissemination of scientific research documents, whether they are published or not. The documents may come from teaching and research institutions in France or abroad, or from public or private research centers.
L'archive ouverte pluridisciplinaire HAL, est destinée au dépôt et à la diffusion de documents scientifiques de niveau recherche, publiés ou non, émanant des établissements d'enseignement et de recherche français ou étrangers, des laboratoires publics ou privés. 


\title{
CO Hydrogenation on Cobalt-Based Catalysts: Tin Poisoning Unravels CO in Hollow Sites as a Main Surface Intermediate
}

\author{
Anaëlle Paredes-Nunez, Davide Lorito, Laurence Burel, Debora Motta-Meira, \\ Giovanni Agostini, Nolven Guilhaume, Yves Schuurman, and Frederic Meunier*
}

\begin{abstract}
Site poisoning is a powerful method to unravel the nature of active sites or reaction intermediates. The nature of the intermediates involved in the hydrogenation of $\mathrm{CO}$ was unraveled by poisoning alumina-supported cobalt catalysts with various concentrations of tin. The rate of formation of the main reaction products (methane and propylene) was found to be proportional to the concentration of multi-bonded $\mathrm{CO}$, likely located in hollow sites. The specific rate of decomposition of these species was sufficient to account for the formation of the main products. These hollow-CO are proposed to be main reaction intermediates in the hydrogenation of $\mathrm{CO}$ under the reaction conditions used here, while linear $\mathrm{CO}$ are mostly spectators.
\end{abstract}

$S_{\mathrm{v}}$ ynthetic fuels and base chemicals can be obtained from both fossil and renewable sources through the catalytic conversion of synthesis gas (syngas, a mixture of carbon oxides and dihydrogen). ${ }^{[1-4]}$ Cobalt-based catalysts are the most important formulations regarding the conversion of syngas to synthetic fuels via Fischer-Tropsch synthesis. ${ }^{[3]}$ The nature of the reaction mechanism of the Fischer-Tropsch synthesis is still a matter of debate, as well as the nature of the active sites. ${ }^{[5-8]}$

IR spectroscopy is a powerful technique for investigating the surface sites and the nature of the reaction intermediates, especially because $\mathrm{CO}$ is both a reactant and a molecular probe that can be used to characterize metal surfaces under reaction conditions. IR studies were previously used to investigate the role of formates, which had been proposed as a precursor of methane or methanol. ${ }^{[9]}$ Our recent quantitative IR studies have shown that formates located near to the alumina-cobalt interface could potentially be the sole precursors of methanol, while not those of methane and propene, which were the main reaction products. ${ }^{[10]}$ The present contribution will now quantitatively investigate the role of adsorbed $\mathrm{CO}$ present over alumina-supported cobalt catalysts.

[*] Dr. A. Paredes-Nunez, D. Lorito, Dr. L. Burel, N. Guilhaume, Dr. Y. Schuurman, Dr. F. Meunier Institut de Recherches sur la Catalyse et l'Environnement de Lyon, Univ Lyon, Université Lyon 1, CNRS

2, Av. Albert Einstein, 69626 Villeurbanne (France)

E-mail: fcm@ircelyon.univ-lyon1.fr

Dr. D. Motta-Meira, Dr. G. Agostini

European Synchrotron Radiation Facility (ESRF)

6 Rue Jules Horowitz, BP 220, Grenoble, Cedex 938043 (France)
We recently reported that the most active cobalt sites were possibly those associated with the formation of bridged/ multi-bonded $\mathrm{CO}$, which are thought to be located at the particle edges or steps. This conclusion was reached by noting that the poisoning of cobalt by chloride affected more the IR band intensity associated with this bridge/multi-bonded $\mathrm{CO}$ than that of linear (that is, on-top) $\mathrm{CO}^{[11]}$

In 1980, Fujimoto and his group suggested for the first time that bridged carbonyls could be active intermediate during $\mathrm{CO}$ hydrogenation over $\mathrm{Ru}$ and $\mathrm{Rh}$ catalysts. ${ }^{[12]} \mathrm{On}$ both catalysts, bridged $\mathrm{CO}$ were hydrogenated (mainly to methane) at a lower temperature than that needed to hydrogenate linear CO. Several other groups proposed that bridged $\mathrm{CO}$ formed over cobalt-based catalysts could be involved in the catalytic activity, ${ }^{[13-22]}$ yet no quantitative structure-activity relationship has yet been reported to the best of our knowledge.

We report herein a quantitative operando diffuse reflectance FTIR spectroscopy (DRIFTS) study in which the hydrogenation of $\mathrm{CO}$ is monitored on Sn-modified $\mathrm{Co} / \mathrm{Al}_{2} \mathrm{O}_{3}$ catalysts under differential reaction conditions. DRIFTS enables monitoring the state of the cobalt surface, in particular the various adsorbed $\mathrm{CO}$ species formed under reaction conditions. ${ }^{[23-25]} \mathrm{Sn}$ was used as a modifier because it is expected to remain strongly adsorbed on the cobalt active phase, unlike chlorine used in our previous study, and does not adsorb CO under our conditions, ${ }^{[26,27]}$ thereby facilitating DRIFTS spectra interpretation.

The description of the experimental setup and the preparation of the catalyst samples (Table 1) are detailed in the experimental section (see the Supporting Information).

Typical TEM images show that the cobalt particle size distribution is narrow and centered for all samples around 9$12 \mathrm{~nm}$ (Supporting Information, Figure S1 A-D). Metal

Table 1: Specific surface area, metal loading, and cobalt dispersion of the as-prepared catalysts.

\begin{tabular}{lllllll}
\hline $\begin{array}{l}\text { Sn/Co } \\
\text { molar } \\
\text { ratio }\end{array}$ & $\begin{array}{l}\text { BET sur- } \\
\text { face } \\
\text { area } \\
{\left[\mathrm{m}^{2} \mathrm{~g}^{-1}\right]}\end{array}$ & $\begin{array}{l}\mathrm{Co} \\
{[\mathrm{wt} \%]}\end{array}$ & $\begin{array}{l}\mathrm{Sn} \\
{[\mathrm{wt} \%]}\end{array}$ & $\begin{array}{l}\text { Metal dis- } \\
\text { persion } \\
{[\%]}\end{array}$ & $\begin{array}{l}\text { Adsorbed } \\
\mathrm{CO}^{[\mathrm{b}]} \\
{\left[\mu \mathrm{molg}^{-1}\right]}\end{array}$ & $\begin{array}{l}\text { Adsorbed } \\
\mathrm{H}_{2}^{[c]} \\
{\left[\mu \mathrm{molg}^{-1}\right]}\end{array}$ \\
\hline Co & 113 & 15.3 & 0 & 7.0 & $143 \pm 10$ & 73 \\
$1: 120$ & 107 & 14.3 & 0.24 & 9.8 & $160 \pm 10$ & 50 \\
$1: 60$ & 102 & 14.4 & 0.52 & 9.2 & $156 \pm 10$ & 33 \\
$1: 30$ & 119 & 14.3 & 1.1 & 7.0 & $103 \pm 6$ & 2 \\
\hline
\end{tabular}

[a] from TEM analyses. [b] From SSITKA experiments (Supporting Information, Figure S5). [c] From chemisorption experiments (Supporting Information, Figure S6). 
(essentially cobalt) dispersions based on the TEM-derived size distributions are reported in Table 1.

The combined catalytic and DRIFTS experiments were carried as follows. About $25 \mathrm{mg}$ of sample were placed in the DRIFTS cell and reduced in situ at $450{ }^{\circ} \mathrm{C}$ for $1 \mathrm{~h}$. The temperature was then set at $220^{\circ} \mathrm{C}$ and the feed $(30 \% \mathrm{CO}+$ $60 \% \mathrm{H}_{2} / \mathrm{He}$ ) was introduced. The reactions were carried out at atmospheric pressure.

Typical operando DRIFTS spectra recorded over a period of $18 \mathrm{~h}$ are shown in the Supporting Information, Figure S2 for the Sn-free catalyst and are similar to those described in details elsewhere. ${ }^{[11,23]}$ In brief, the bands at about 3000-2800 and below $1650 \mathrm{~cm}^{-1}$ are essentially related to hydrocarbon waxes and formates $/ \mathrm{CO}_{2}$ adsorbed on the support, respectively. The bands of main interest to this study are adsorbed on metallic cobalt: on-top (linearly) at $2031 \mathrm{~cm}^{-1}$ and bridged/ multi-bonded species below $2000 \mathrm{~cm}^{-1}$. The intensity of these bands was essentially constant after $3 \mathrm{~h}$, except for those associated with waxes that continued growing with time.

The rates of formation of the main products measured at the outlet of the DRIFTS cell are shown in the Supporting Information, Figure S3. The selectivity to methane and propene of the samples could not be determined with any satisfactory precision because of the low level of $\mathrm{CO}$ conversion (well below $5 \%$, inducing a large relative error on selectivities). Shi et al., ${ }^{[28]}$ who developed the synthesis method used here to prepare the Sn-free sample, reported at 1.0 $\mathrm{MPa}$ selectivities to methane and propene of $40 \%$ and $2 \%$, respectively. The selectivity to methane obtained here at atmopheric pressure should be larger and methane be by far the main reaction product. The data reported here were focused on rates of product formation, which could be determined directly without using $\mathrm{CO}$ conversion by neglecting the change of moles of gases due to the reaction at these low levels of conversion.

An induction period of about $3 \mathrm{~h}$ was observed during which the rates of formation decreased rapidly before becoming steadier (Supporting Information, Figure S3). The Sn-free sample (red symbols) was the most active catalyst, as the activity markedly decreased with increasing content of tin. The DRIFTS and activity data are consistent with an initial surface reconstruction taking place over ca. $3 \mathrm{~h}$, as suggested earlier, ${ }^{[23]}$ while the slower long term deactivation may be partly related to wax deposition.

The contribution of gas-phase CO on the DRIFTS spectra could be precisely subtracted according to the method reported elsewhere ${ }^{[29]}$ to facilitate the analysis of adsorbed $\mathrm{CO}$ bands. The signal obtained at pseudo-steady-state (that is, $>20 \mathrm{~h}$ on stream) of the $\mathrm{Sn}$-modified samples was compared to that of the Co/alumina (Figure 1). Band intensities were normalized with respect to the signal maximum in this region, which turned out to be located at $2031 \mathrm{~cm}^{-1}$ in all spectra. This position corresponds to linearly bound $\mathrm{CO}$ on metallic cobalt.

Interestingly, the intensity of the bridged/multi-bonded CO located in the region below $2000 \mathrm{~cm}^{-1}$ decreased gradually with increasing Sn content. A decomposition of the DRIFTS bands was carried out to determine the contribution of bridged species (Supporting Information, Figure S4). A single band located at about $1860 \mathrm{~cm}^{-1}$ was sufficient to

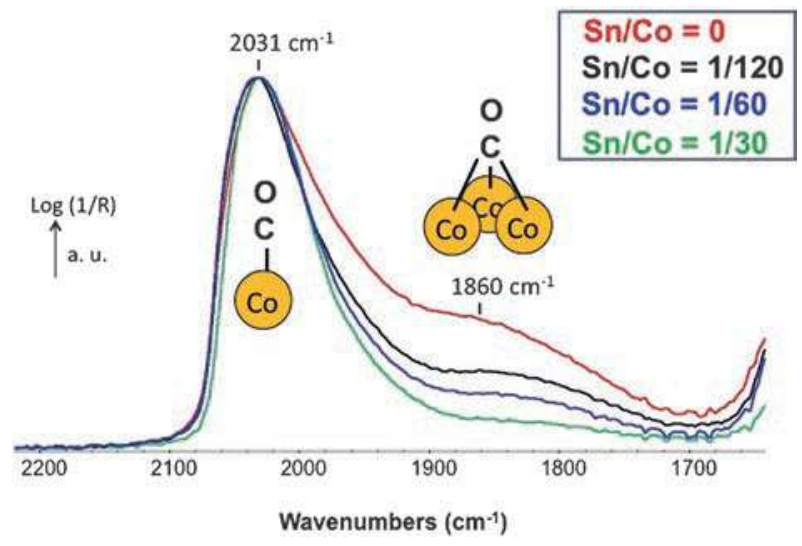

Figure 1. Operando DRIFTS spectra collected after $23 \mathrm{~h}$ at $220^{\circ} \mathrm{C}$ under $30 \% \mathrm{CO}+60 \% \mathrm{H}_{2} / \mathrm{He}$ over $\mathrm{Co} /$ alumina (red) and the Snmodified samples $\mathrm{Sn} / \mathrm{Co}=1: 120$ (black), $\mathrm{Sn} / \mathrm{Co}=1: 60$ (blue), and Sn/ $\mathrm{Co}=1: 30$ (green). Total flow was $30 \mathrm{~mL} \mathrm{~min}^{-1}$. The signal of gaseous $\mathrm{CO}$ was subtracted. The spectra were normalized with respect to the $2031 \mathrm{~cm}^{-1}$ band.

satisfactory represent the DRIFTS signal in this region. According to Weststrate et al. ${ }^{[30]}$ this band can be assigned to $\mathrm{CO}$ adsorbed on hollow sites (thereafter noted "hollowCO"). The molar fractions of linear and hollow-CO could be determined from the proportion of hollow-CO DRIFTS bands (Supporting Information, Figure S4), taking into account that the molar absorption coefficient of linear $\mathrm{CO}$ is twice as high as that of hollow-CO. ${ }^{[30]}$

The specific concentrations of reversibly adsorbed $\mathrm{CO}$ over each of the samples were determined through isotopic exchange under reaction conditions at $220^{\circ} \mathrm{C}$. Typical normalized exchange plots obtained during the exchange ${ }^{12} \mathrm{CO}-$ ${ }^{13} \mathrm{CO}$ are shown in the Supporting Information, Figure S5 and the results are gathered in Table 1 . The number of $\mathrm{CO}$ reversibly adsorbed was essentially unchanged (ca. $150 \mu \mathrm{molg}^{-1}$ ) for the two samples least loaded with $\mathrm{Sn}$ as compared to the case of the Sn-free sample (Table 1). A significant lower CO adsorption capacity (ca. $103 \mu \mathrm{molg}^{-1}$ ) was only noted for the most Sn-loaded material.

The effect of $\mathrm{Sn}$ on the adsorption of $\mathrm{H}_{2}$ was also investigated (Supporting Information, Figure S6) and is discussed in detail in the Supporting Information, section Discussion D1.

The plots of the rates of formation of methane and propene as a function of the concentration of hollow-CO (assumed to be equal to the product of the concentration of reversibly adsorbed $\mathrm{CO}$ and the molar fraction of hollow-CO) are given in Figure 2 A. Linear relationships were obtained, highlighting a direct correlation between the concentration of hollow-CO and the rate of formation of the two major reaction products.

The minor offset of the data points at the highest concentration (Figure 2A, red symbols) is most likely due to an underestimation of the true concentration of adsorbed $\mathrm{CO}$ from the SSITKA experiments (Table 1). In fact, the rate plots as a function the IR band fraction, which is not affected by the lower precision of the SSITKA data, exhibit much clearer linear relationships (Figure 2B). The data used to 
(A)

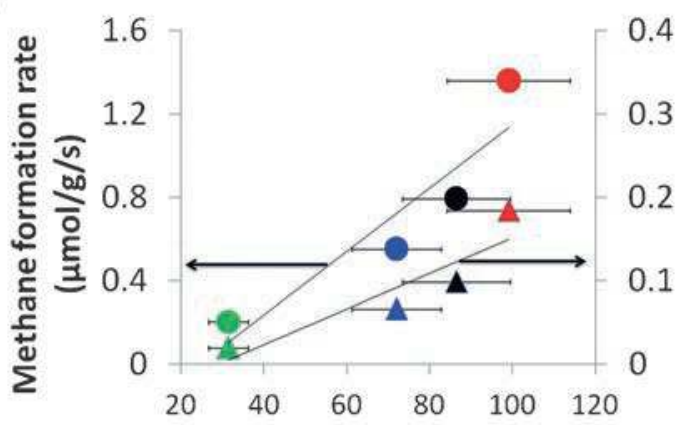

Hollow-CO concentration $(\mu \mathrm{mol} / \mathrm{g}$ )

(B)

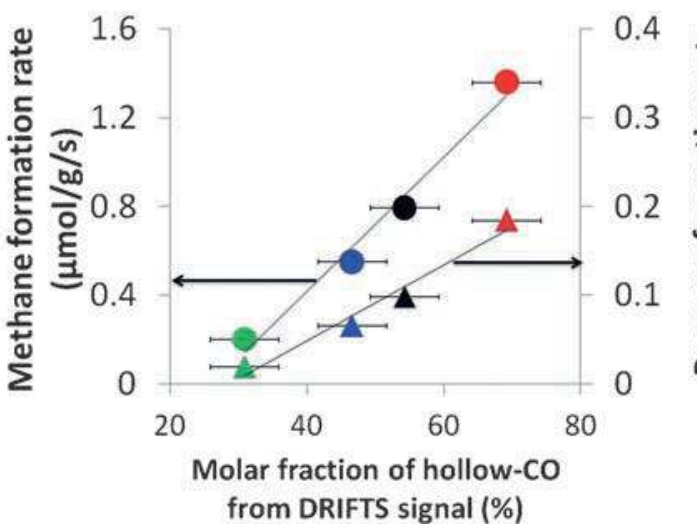

Figure 2. Methane $(\bullet)$ and propene $(\mathbf{\Delta})$ production as a function of the concentration of hollow-CO expressed A) in $\mu \mathrm{mol} \mathrm{g}^{-1}$ and B) as a molar fraction of adsorbed CO determined by DRIFTS measured over the alumina-supported cobalt (red symbols) and the three Snmodified samples: $\mathrm{Sn} / \mathrm{Co}=1: 120$ (black), $\mathrm{Sn} / \mathrm{Co}=1: 60$ (blue), and $\mathrm{Sn} / \mathrm{Co}=1: 30$ (green). Total flow was $30 \mathrm{~mL} \mathrm{~min}^{-1}$.

draw Figure 2B were collected from operando experiments carried out entirely on the DRIFTS cell, while those in Figure $2 \mathrm{~A}$ also relied on supplementary data obtained from the plug-flow SSITKA reactor, hence leading to lower precision. Overall the data clearly indicate that hollow-CO was, at least, a marker of the catalytic activity, if not a main reaction intermediate.

A large number of other samples were tested, which differed in the nature of the pre-treatment (Supporting Information, Table S1). Essentially linear relationships were obtained when the product rate vs. hollow-CO fraction of all these samples was plotted (Supporting Information, Figure S7), stressing the universal nature of the relationship between hollow-CO and catalytic activity over this type of Co-Sn formulations.

Additional experiments were carried out to estimate the initial decomposition rate of adsorbed $\mathrm{CO}$ by removing $\mathrm{CO}(\mathrm{g})$ from the feed. The decomposition rate of adsorbed $\mathrm{CO}$ over the $\mathrm{Sn}$-free sample was about 5-fold faster under $\mathrm{H}_{2}$ than under He (Figure 3). This indicates that adsorbed $\mathrm{CO}$ was mainly decomposed through hydrogenation to hydrocarbons rather than desorption to $\mathrm{CO}(\mathrm{g})$ over the most active sample.

In contrast, essentially identical decomposition rates under $\mathrm{H}_{2}$ and $\mathrm{He}$ were obtained for the sample most poisoned

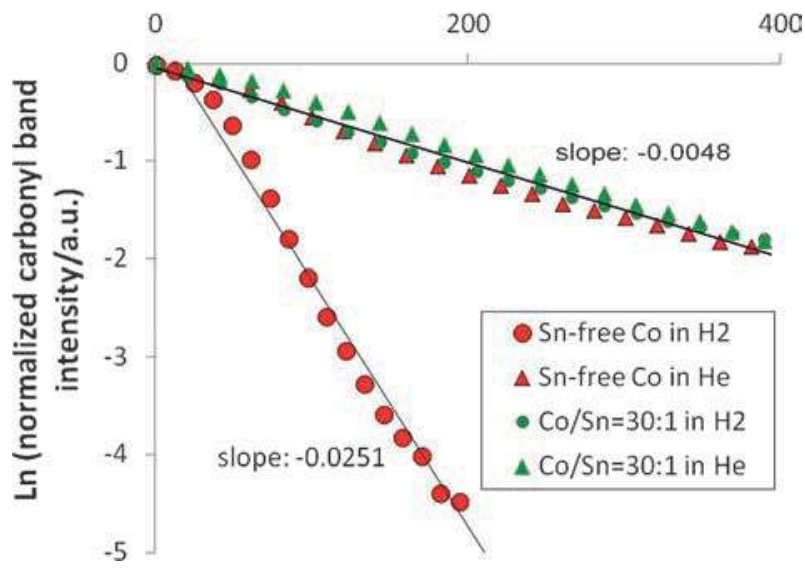

Figure 3. Logarithm of the DRIFTS band area of $\mathrm{CO}$ (ads) present over (red symbols) Sn-free Co/alumina and (green symbols) $\mathrm{Co} / \mathrm{Sn}=30: 1$ sample at $220^{\circ} \mathrm{C}$ under a stream of $20 \mathrm{~mL} \mathrm{~min}^{-1}$ of $(\bullet)$ pure $\mathrm{H}_{2}$ and (४) pure $\mathrm{He}$ as a function of time following the removal of $\mathrm{CO}(\mathrm{g})$. The feed was composed of $30 \% \mathrm{CO}+60 \% \mathrm{H}_{2} / \mathrm{He}$ prior to $\mathrm{CO}$ removal. The rate constants of $\mathrm{CO}$ (ads) decomposition were equal to the absolute value of the slope of the corresponding lines.

with tin, $\mathrm{Co} / \mathrm{Sn}=30: 1$ (Figure 3). This indicates that adsorbed $\mathrm{CO}$ mostly desorbed as unreacted $\mathrm{CO}(\mathrm{g})$ over the least active sample, which exhibited the largest proportion of linear $\mathrm{CO}$ (Figure 1). These observations underline that linear $\mathrm{CO}$ were unreactive spectators.

Interestingly, the initial rate of $\mathrm{CO}$ decomposition was almost identical over the Sn-free sample under $\mathrm{He}$ and the most poisoned sample (whether under $\mathrm{He}$ or $\mathrm{H}_{2}$; Figure 3). It is likely that at $220^{\circ} \mathrm{C}$ surface diffusion allowed rapid transfer of adsorbed $\mathrm{CO}$ between hollow-CO and linear $\mathrm{CO}$ sites. Thus, hollow-CO, which are expected to be more strongly bonded than linear $\mathrm{CO}$, were probably removed in the absence of $\mathrm{H}_{2}$ through transfer onto sites forming linear species before desorbing as $\mathrm{CO}(\mathrm{g})$.

The decay of the DRIFTS signal of adsorbed $\mathrm{CO}$ under $\mathrm{H}_{2}$ followed first order kinetics for all samples (Supporting Information, Figure S8), suggesting uniform decomposition in all cases, even when both hollow and linear $\mathrm{CO}$ were present in similar proportions. Such behavior is again consistent with a rapid exchange of adsorbed $\mathrm{CO}$ between hollow and top sites at $220^{\circ} \mathrm{C}$, decomposition occurring then through the fastest pathway available: hydrogenation if hollow sites were available, otherwise through desorption as $\mathrm{CO}(\mathrm{g})$ on top sites. The rate constant of decomposition under $\mathrm{H}_{2}$ was determined from the slope of best fit lines (Supporting Information, Figure S8).

The specific rate of decomposition of hollow-CO could thus be calculated (that is, rate $=$ rate constant $x$ hollow-CO concentration) and compared to the specific rates of methane and propene formation (Figure 4). The decomposition rate of hollow-CO was similar or higher than the sum of methane and propene formation. These observations would be fully consistent with hollow-CO being a main surface intermediate in the formation of these hydrocarbons under the present conditions. The difference between the two rates could be 


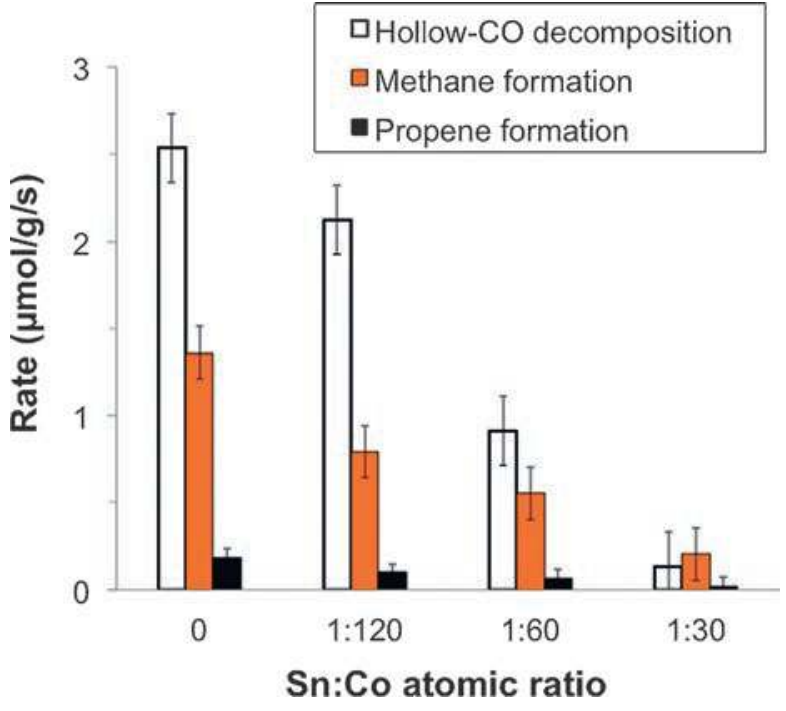

Figure 4. Rates of formation of methane and propene, and rate of decomposition of hollow-CO after $22 \mathrm{~h}$ at $220^{\circ} \mathrm{C}$ over $\mathrm{Al}_{2} \mathrm{O}_{3}$-supported cobalt and three Sn-modified samples. Feed: $30 \% \mathrm{CO}+60 \% \mathrm{H}_{2}$ in $\mathrm{He}, P=1 \mathrm{~atm}$

associated mostly with the formation of higher hydrocarbons, which were not measured here, and some desorption as $\mathrm{CO}(\mathrm{g})$. The rate difference of about $50 \%$ is actually consistent with a selectivity to methane of about $50 \%$ expected at atmospheric pressure.

In conclusion, the present quantitative operando study of syngas reaction over cobalt-based catalysts demonstrates quantitative relationships between hollow-CO species (that is, IR mol fraction and decomposition rates) and the rate of formation of the main reaction products methane and propene. More work is needed to determine the exact nature of these crucial reaction sites and confirm their relevance at higher operating pressures.

\section{Acknowledgements}

A.P.-N. and D.L. acknowledge PhD scholarships from the French Ministry of Education and Research at the University of Lyon. The European Synchrotron Radiation Facility (ESRF) is acknowledged for the allocated beamtime (IHCH4670).

\section{Conflict of interest}

The authors declare no conflict of interest.

Keywords: carbon monoxide - cobalt · FischerTropsch reaction $\cdot$ heterogeneous catalysis $\cdot$ tin
[1] U. M. Graham, G. Jacobs, M. K. Gnanamani, S. M. Lipka, W. D. Shafer, C. R. Swartz, T. Jermwongratanachai, R. Chen, F. Rogers, B. H. Davis, ACS Catal. 2014, 4, 1662-1672.

[2] J.-C. Kim, S. Lee, K. Cho, K. Na, C. Lee, R. Ryoo, ACS Catal. 2014, 4, 3919-3927.

[3] A. Y. Khodakov, W. Chu, P. Fongarland, Chem. Rev. 2007, 107, $1692-1744$.

[4] P. Munnik, N. A. Krans, P. E. de Jongh, K. P. de Jong, ACS Catal. 2014, 4, 3219-3226.

[5] I. A. W. Filot, R. A. van Santen, E. J. M. Hensen, Angew. Chem. Int. Ed. 2014, 53, 12746-12750; Angew. Chem. 2014, 126, 12960 12964.

[6] W. T. Ralston, G. Melaet, T. Saephan, G. A. Somorjai, Angew. Chem. Int. Ed. 2017, 56, 7415-7419; Angew. Chem. 2017, 129, $7523-7527$.

[7] N. Fischer, E. van Steen, M. Claeys, J. Catal. 2013, 299, 67-80.

[8] J. Schweicher, A. Bundhoo, N. Kruse, J. Am. Chem. Soc. 2012, 134, 16135-16138.

[9] V. Sanchez-Escribano, M. A. Larrubia Vargas, E. Finocchio, G. Busca, Appl. Catal. A 2007, 316, 68-74.

[10] D. Lorito, A. Paredes-Nunez, C. Mirodatos, Y. Schuurman, F. C. Meunier, Catal. Today 2016, 259, $192-196$.

[11] A. Paredes-Nunez, D. Lorito, Y. Schuurman, N. Guilhaume, F. C. Meunier, J. Catal. 2015, 329, 229-236.

[12] K. Fujimoto, M. Kameyama, T. Kunugi, J. Catal. 1980, 61, 7-14.

[13] S. Sun, N. Tsubaki, K. Fujimoto, Appl. Catal. A 2000, 202, 121 131.

[14] S. Sun, K. Fujimoto, Y. Zhang, N. Tsubaki, Catal. Commun. 2003, 4, $361-364$.

[15] J. Zhang, J. Chen, J. Ren, Y. Sun, Appl. Catal. A 2003, 243, 121 133.

[16] J. Zhang, J. Chen, J. Ren, Y. Li, Y. Sun, Fuel 2003, 82, 581-586.

[17] N. Tsubaki, S. Sun, K. Fujimoto, J. Catal. 2001, 199, 236-246.

[18] D. Song, J. Li, J. Mol. Catal. A 2006, 247, 206-212.

[19] H. Xiong, Y. Zhang, K. Liew, J. Li, J. Mol. Catal. A 2008, 295, 68 76.

[20] X. Sun, X. Zhang, Y. Zhang, N. Tsubaki, Appl. Catal. A 2010, 377, 134-139.

[21] Y. Zhang, S. Nagamori, S. Hinchiranan, T. Vitidsant, N. Tsubaki, Energy Fuels 2006, 20, 417-421.

[22] F. Morales, E. de Smit, F. M. F. de Groot, T. Visser, B. M. Weckhuysen, J. Catal. 2007, 246, 91 - 99.

[23] A. Paredes-Nunez, D. Lorito, N. Guilhaume, C. Mirodatos, Y. Schuurman, F. C. Meunier, Catal. Today 2015, 242, 178-183.

[24] J. Schweicher, A. Frennet, N. Kruse, H. Daly, F. C. Meunier, J. Phys. Chem. C 2010, 114, 2248-2255.

[25] D. C. Song, J. L. Li, Q. Cai, J. Phys. Chem. C 2007, 111, $18970-$ 11879.

[26] P. Liu, A. Logadottir, J. K. Nørskov, Electrochim. Acta 2003, 48, $3731-3742$.

[27] A. Moscu, L. Veyre, C. Thieuleux, F. Meunier, Y. Schuurman, Catal. Today 2015, 258, 241-246.

[28] L. Shi, C. Zeng, Q. Lin, W. Niu, N. Tsubaki, Catal. Today 2014, $228,206-211$

[29] A. Paredes-Nunez, I. Jbir, D. Bianchi, F. C. Meunier, Appl. Catal. A 2015, 315, 17-22.

[30] C. J. Weststrate, J. van de Loosdrecht, J. W. Niemantsverdriet, J. Catal. 2016, 342, 1-16. 